\title{
Use of a hydroalcoholic extract of Salix alba L. bark powder in diets of broilers exposed to high heat stress
}

\author{
M. Saracila ${ }^{1,2 \#}$, T.D. Panaite $^{1}$, C. Soica ${ }^{1}$, C. Tabuc ${ }^{1}$, M. Olteanu ${ }^{1}$, C. Predescu ${ }^{2}$, \\ C.M. Rotar $^{1}$ \& R.D. Criste ${ }^{1}$ \\ ${ }^{1}$ National Research-Development Institute for Animal Biology and Nutrition (IBNA), 1, Calea Bucuresti, Balotesti, \\ 077015, Ilfov, Romania \\ ${ }^{2}$ University of Agronomic Sciences and Veterinary Medicine, Faculty of Veterinary Medicine, 105 Splaiul Independentei, \\ 050097, Bucharest, Romania
}

(Received 30 April 2019; Accepted 20 September 2019; First published online 18 November 2019)

Copyright resides with the authors in terms of the Creative Commons Attribution 4.0 South African Licence.

See: http://creativecommons.org/licenses/by/4.0/za

Condition of use: The user may copy, distribute, transmit and adapt the work, but must recognise the authors and the South African Journal of Animal Science.

\begin{abstract}
A study was conducted to determine the effects of dietary hydroalcoholic willow bark extract powder (HWE) supplemented to broilers (14-42 days old) that were exposed to heat stress, on the performance, serum biochemical parameters, liver oxidative status and caecal microflora. The feeding trial was conducted on 120 Cobb 500 broilers (14 days old), assigned to three treatments (T0, T25, and T50), each treatment consisting of eight replicates (five chicks per replicate). The broilers were housed in an experimental hall at a $32{ }^{\circ} \mathrm{C}$ constant temperature and 23 hours light regimen. Unlike the dietary control treatment (T0), the experimental treatments were supplemented with $25 \mathrm{~g} \mathrm{HWE}$ powder/100 kg diet (T25), and $50 \mathrm{~g} \mathrm{HWE}$ powder $100 \mathrm{~kg}$ diet (T50), respectively. Dietary HWE powder did not affect the broilers' performance significantly (14-42 days). A significantly lower amount of malondialdehyde was noticed in the liver of broilers from T25 and T50 treatments in comparison with broilers from T0. Also, the serum cholesterol, triglycerides and alanine aminotransferase were significantly lower in broilers fed with T50, compared with those fed with T0. At 35 and at 42 days, the broilers from T25 and T50 recorded a significantly lower number of $E$. coli and staphylococci and a higher number of lactobacilli in the caecum than those of T0. It could be concluded that supplementation of dietary HWE powder reduced some of the adverse effects of heat stress, the most effective being the level of $50 \mathrm{~g} / 100 \mathrm{~kg}$ diet.
\end{abstract}

Keywords: biochemical parameters, caecal microflora, high temperature, liver oxidative status

"Corresponding author: mihaela.saracila@yahoo.com

\section{Introduction}

Global warming as a result of increased industrialization and environmental degradation has led to a continuous increase in ambient temperature, thereby making heat stress a major problem of livestock farming, particularly in the poultry sector (Daghir, 2009; Pirgozliev et al., 2019). Modern poultry species such as broiler chickens are highly sensitive to heat stress because of feather cover, lack of sudoriferous glands and fast growth (St-Pierre et al., 2010; Piestun et al., 2013). A temperature above $30^{\circ} \mathrm{C}$ represents a heatstressed condition for birds and is one of the most common stressors that affect the production criteria in poultry (Kamboh et al., 2013; Ma et al., 2015). Studies on broilers showed that heat stress disrupted the equilibrium between antioxidants and reactive oxygen species (Gu et al., 2012; Nisar et al., 2013), increased tissue damage (Abidin \& Khatoon, 2013; Huang et al., 2018), impaired metabolic function (Habibian et al., 2014), and even changed the bacterial composition in the intestine (Wang et al., 2018; Shi et al., 2019).

An additional pressure factor for the European poultry producers, besides heat stress, is the ban on antibiotic growth promoters in poultry diets in Europe (Castanon, 2007). Thus, the industry must look for viable alternatives that can improve performance, protect animal health and maintain profit margins (Basmacıoğlu et al., 2004; Yegani \& Korver, 2008; Tugay et al., 2015). In recent years, poultry producers and nutritionists have paid greater attention to the use of bioactive compounds from natural resources in broiler diets to alleviate the impact of high environmental temperature, such as changes in feeding and drinking water management. Seidavi et al. (2018) reported that many products in the form of powders, 
extracts and essential oils from many trees and shrubs have been included in broiler diet because of their bacterial, antioxidant, and cholesterol lowering properties. In this context, feed additives that contain phenolics could improve the resistance of broilers to heat stress (Chang Song et al., 2017), lower the rectal temperature (Al-Fataftah \& Abdelqader, 2013) and reduce pathogens such as C. perfringens and E. coli in the broiler gut (Jakubcova et al., 2014). These effects are due largely to their well-known antioxidant and antibacterial activity (Gavris et al., 2019). Many phytoadditives have been used in the diets of broilers that are reared under heat stress, such as grape seed extract (Hajati et al., 2015), oregano (Criste et al., 2017), peppermint (Arab Ameri et al., 2016), artemisia (Panaite et al., 2018; Saracila et al., 2018), rosehip (Criste et al., 2017; Vlaicu et al., 2017), and willow bark hydroglyceroalcoholic extract (Saracila et al., 2018). These feeding studies aimed to determine the effects of these sources on broiler performance, serum biochemical parameters and the balance of gut microflora.

A liquid extract obtained from boiling willow bark (Salix alba) has been used by southern Romanian farmers as a traditional remedy for chicks with enteritis. The European Pharmacopoeia defines willow bark as the whole or fragmented dry bark of young shoots or dry branches of various Salix species, including Salix purpurea L., Salix daphnoides ViLL. and Salix fragilis L. (Nahrstedt et al., 2007). Its use has been widely accepted following the positive monographs of European Scientific Cooperative on Phytotherapy (ESCOP) and the European Commission, and is supported by many clinical studies. Zabihi et al. (2018) show that although salicin is the main active compound of the willow bark, its polyphenols and flavonoids must receive due attention. Other authors (Sulaiman et al., 2013; Shara \& Stohs, 2015) showed that willow bark contains flavonoids and polyphenols that contribute synergistically to the beneficial effects of Salix alba and may be more important than those of synthetic salicylic acid. Salix alba extract has free radical scavenging activity and can be used as a radical inhibitor or scavenger, with the possibility of acting as a primary antioxidant (Sulaiman et al., 2013). When willow bark is used, its toxicity is much less than aspirin toxicity, owing to the low levels of salicylates in the plant products (Altınterim, 2013). Implications of human use of Salix as a source of acetylsalicylic acid have been studied (Mahdi, 2010; Vlachojannis et al., 2011; Ishikado et al., 2013). However, only a few studies have been conducted over the last 5-10 years on the effect of using Salix species extracts on broilers that are raised under heat-stress conditions. For example, Al-Fataftah \& Abdelqader (2013) found that Salix babylonica extract improved heat tolerance, feed intake, body weight gain, and feed conversion ratio, and reduced mortality of heat-stressed broilers (35 $\left.{ }^{\circ} \mathrm{C}\right)$ with similar efficacy to acetylsalicylic acid. El-Soud et al. (2006) observed significant decreases in serum cholesterol levels of Japanese quail under heat stress that were fed diets containing $0.025 \%, 0.05 \%$ or $0.1 \%$ acetylsalicylic acid.

Effects of diet supplementation with powdered hydroalcoholic willow bark extract on performance, health and oxidative status and caecal microflora of broilers exposed to heat stress were not found in the literature. Therefore, the present study was conducted to investigate whether dietary supplementation of broiler chicks between the ages of 14 and 42 days with HWE powder alleviates the negative effects of heat stress on performance, serum biochemical parameters, liver oxidative status and the caecal microflora of broilers.

\section{Materials and Methods}

The feeding trial was conducted in an experimental hall at the Laboratory of Chemistry and Nutrition Physiology of the National Research Development Institute for Animal Biology and Nutrition (IBNA-Balotesti, Romania) according to an experimental protocol (no. 3005/15.05.2018). This protocol was approved by the Ethics Commission of the Institute.

The feeding trial used a total of 120 Cobb 500 broiler chicks, males and females, which were purchased from a local hatchery (SEMAR Trading S.R.L., Ploiesti, Romania). Upon arrival, the chicks were weighed individually and randomly housed in three-tiered digestibility cages (5 chicks/cage), allowing a daily recording of the feed intake and excreta. Throughout the experimental period, the environmental temperature of the experimental hall was kept constant at $32{ }^{\circ} \mathrm{C}$. The humidity was $36 \%$, with $0.38 \%$ ventilation/broiler, and $899 \mathrm{ppm} \mathrm{CO}_{2}$ emission. The light regimen was appropriate to the age of the chicks, that is, 23 hours light/1 hour darkness. Up to the age of 14 days, they received a commercial starter diet (3000 kcal/kg metabolizable energy, 22\% crude protein). At 14 days, the chicks were weighed individually and assigned to three treatments (T0, T25, and T50), each treatment consisting of 8 replicates of 5 chicks/ replicate and thus 40 chicks/treatment. At the onset of the experiment (14 days) the chicks assigned to each treatment were similar in bodyweight: $400.64 \pm 11.85 \mathrm{~g}$ (T0), $400.67 \pm 10.35 \mathrm{~g}$ (T25), and $400.36 \pm 9.56 \mathrm{~g}$ (T50). Table 1 shows the composition of the grower (24-35 days) and finisher (35-42 days) diets. Unlike the dietary control treatment (T0), the chicks that were assigned to the treatments T25 and T50 were supplemented with $25 \mathrm{~g} \mathrm{HWE}$ powder/100 kg diet and $50 \mathrm{~g} \mathrm{HWE}$ powder/100 kg diet, respectively (Table 1). 
Table 1 Formulation of diets for broiler chicks to test the efficacy of hydroalcoholic willow bark extract powder in mitigating the effects of heat stress

\begin{tabular}{|c|c|c|c|c|c|c|}
\hline \multirow{2}{*}{ Ingredient } & \multicolumn{3}{|c|}{ Grower stage (14-35 days) } & \multicolumn{3}{|c|}{ Finisher stage (35-42 days) } \\
\hline & TO & T25 & T50 & TO & T25 & T50 \\
\hline \multicolumn{7}{|l|}{$\%$} \\
\hline Corn & 62.000 & 61.975 & 61.950 & 60.500 & 60.475 & 60.000 \\
\hline Soybean meal & 26.580 & 26.58 & 26.580 & 25.460 & 25.460 & 25.460 \\
\hline Gluten & 4.000 & 4.000 & 4.000 & 6.000 & 6.000 & 6.000 \\
\hline Oil & 2.500 & 2.500 & 2.500 & 3.750 & 3.750 & 3.750 \\
\hline Hydroalcoholic willow bark extract powder & & 0.025 & 0.050 & & 0.025 & 0.050 \\
\hline Calcium carbonate & 1.400 & 1.400 & 1.400 & 1.330 & 1.330 & 1.330 \\
\hline Monocalcium phosphate & 1.360 & 1.360 & 1.360 & 1.130 & 1.130 & 1.130 \\
\hline Salt & 0.370 & 0.370 & 0.370 & 0.330 & 0.330 & 0.330 \\
\hline Methionine & 0.260 & 0.260 & 0.260 & 0.250 & 0.250 & 0.250 \\
\hline Lysine & 0.480 & 0.480 & 0.480 & 0.20 & 0.200 & 0.200 \\
\hline Choline & 0.050 & 0.050 & 0.050 & 0.050 & 0.050 & 0.050 \\
\hline Vitamin-mineral premix* & 1.000 & 1.000 & 1.000 & 1.000 & 1.000 & 1.000 \\
\hline \multicolumn{7}{|l|}{ Ration composition } \\
\hline Metabolizable energy, kcal/kg & 3250.00 & 3250.00 & 3250.00 & 3108.00 & 3108.00 & 3108.00 \\
\hline Dry matter, \% & 90.16 & 90.44 & 90.30 & 89.54 & 89.71 & 89.50 \\
\hline Crude protein, $\%$ & 22.41 & 22.19 & 19.92 & 21.65 & 21.49 & 21.67 \\
\hline Ether extractives, \% & 4.16 & 4.78 & 4.60 & 5.67 & 5.57 & 5.70 \\
\hline Crude fibre, $\%$ & 4.70 & 4.25 & 4.62 & 3.68 & 3.49 & 3.89 \\
\hline Ash, \% & 6.43 & 5.67 & 6.26 & 5.63 & 5.82 & 5.25 \\
\hline Calcium, \% & 0.84 & 0.83 & 0.83 & 0.82 & 0.83 & 0.81 \\
\hline Phosphorus, \% & 0.72 & 0.75 & 0.72 & 0.74 & 0.73 & 0.71 \\
\hline
\end{tabular}

*1 $\mathrm{kg}$ premix contains $1100000 \mathrm{IU} / \mathrm{kg}$ vitamin A; $200000 \mathrm{IU} / \mathrm{kg}$ vitamin D3; $2700 \mathrm{IU} / \mathrm{kg}$ vitamin E; $300 \mathrm{mg} / \mathrm{kg}$ vitamin K; $200 \mathrm{mg} / \mathrm{kg}$ Vit. B1; $400 \mathrm{mg} / \mathrm{kg}$ vitamin B2; $1485 \mathrm{mg} / \mathrm{kg}$ pantothenic acid; $2700 \mathrm{mg} / \mathrm{kg}$ nicotinic acid; $300 \mathrm{mg} / \mathrm{kg}$ vitamin B6; 4 mg/kg Vit. B7; 100 mg/kg vitamin B9; $1.8 \mathrm{mg} / \mathrm{kg}$ vitamin B12; $2000 \mathrm{mg} / \mathrm{kg}$ vitamin C; $8000 \mathrm{mg} / \mathrm{kg}$ manganese; 8000 $\mathrm{mg} / \mathrm{kg}$ iron; $500 \mathrm{mg} / \mathrm{kg}$ copper; $6000 \mathrm{mg} / \mathrm{kg}$ zinc; $37 \mathrm{mg} / \mathrm{kg}$ cobalt; $152 \mathrm{mg} / \mathrm{kg}$ iodine; $18 \mathrm{mg} / \mathrm{kg}$ selenium

The powdered hydroalcoholic willow bark (Salix alba L.) extract containing 98\% salicin was purchased from a commercial company in China (Changsha Vigorous-tech Co., Ltd). The extract had been obtained from dry bark, using hydroalcoholic extraction in grain alcohol and water. Feed and water were provided for ad libitum consumption. Diet formulations were calculated to meet or exceed the minimum requirements for broiler chicks as recommended by Cobb-Vantrese, Inc. (Anonymous, 2015). All diets were fed in mash form.

Throughout the experimental period (14-42 days of broiler age) bodyweight (g), average daily feed intake ( $\mathrm{g}$ feed/broiler/day) were monitored and average daily weight gain ( $\mathrm{g} / \mathrm{broiler} / \mathrm{day})$, and feed conversion ratio (FCR, g feed/g gain) were calculated. Individual bodyweight was recorded weekly. The experiment protocol stipulated that mortality should be recorded daily throughout the experiment.

At 42 days of age, and before slaughter, eight chicks per treatment with bodyweight within $\pm 10 \mathrm{~g}$ standard deviation of the mean treatment weight had their blood aseptically collected from the brachial vein into 9-mL Vacutainers containing $14.3 \mathrm{U} / \mathrm{mL}$ of lithium heparin (Vacutest ${ }^{\circledR}$, Arzergrande, Italy). These samples were used to determine the serum lipid, protein, and enzyme profiles.

One bird from each replication (eight birds per treatment), with bodyweight within $\pm 10 \mathrm{~g}$ standard deviation of the mean treatment weight, was slaughtered on days 35 and 42 by cervical dislocation and bled immediately. Carcasses were eviscerated manually and the gut was carefully excised from the oesophagus to the cloaca. Caecal contents (two caeca per bird) were collected aseptically in sterilized plastic tubes and preserved at $-20^{\circ} \mathrm{C}$ until the bacteriological analyses (E. coli, staphylococci, lactobacilli, Salmonella spp). Any digesta that remained in the two caeca was removed with gentle pressure. Liver tissue was collected 
after removing fat and connective tissue. Liver samples were vacuum packed and stored at $-80{ }^{\circ} \mathrm{C}$ until analysis.

The total phenol content of HWE powder was measured spectrophotometrically according to the FolinCiocalteu method, as described by Untea et al. (2018). The principle is to record the absorbance of a basic extract which, by complexation with the Folin-Ciocalteu reagent, absorbs in Vis domain at $\lambda=732 \mathrm{~nm}$, wavelength. The methanol extract was obtained by extracting $2 \mathrm{~g}$ of sample in $20 \mathrm{~mL}$ methanol (80\%), and kept on a rotary shaker for 24 hours in the dark. The extract was centrifuged at a relative centrifugal force of 1500 times gravity for $10 \mathrm{~min}$ and the supernatant was considered for analysis. The calibration curve of gallic acid was used to determine total phenol compounds, and the results $(n=2)$ were reported as $\mathrm{mg}$ gallic acid equivalents (GAE) per gram sample (mg GAE/g).

The total antioxidant capacity of the willow bark extract was evaluated by the phosphomolybdenum method of Prieto et al. (1999), based on the reduction of Molybdenum(VI) $(\mathrm{Mo}(\mathrm{VI}))$ to $\mathrm{Mo}(\mathrm{V})$ and the further formation of a phosphate-Mo(V) green complex at an acidic $\mathrm{pH}$. The results $(n=2)$ were expressed as mmol equivalent ascorbic acid/kg sample and as mmol equivalent vitamin $\mathrm{E} / \mathrm{kg}$ sample.

Feed samples were taken from each batch of compound feeds and assayed for the chemical proximate composition using the chemical methods from Commission of the European Communities (2009). Dry matter (ISO 6496/2001), crude protein (ISO 5983-2/2009), ether extractives (SR ISO 6492/2001), crude fibre (ISO 6865/2002), and ash (ISO 2171/2010) were determined. Calcium was analysed according to SR ISO 6490-1/1996 and phosphorus according to SR ISO 6491:1983.

Blood samples were centrifuged at $775 \times \mathrm{g}$ for $25 \mathrm{~min}$ at $4{ }^{\circ} \mathrm{C}$. The supernatant was used to determine these biochemical markers: energy profile (cholesterol, triglyceride), protein profile (albumin, total protein), and enzyme profile (alanine aminotransferase and aspartate aminotransferase). The biochemical parameters were determined on an automatic BS-130 chemistry analyser (Bio- Medical Electronics Co., Ltd, China).

Thiobarbituric acid reactive species assay from liver was carried out according to the method reported by de Zwart et al. (1999) based on the absorbance measurement of the rose complex formed from the reaction of malondialdehyde and two molecules of thiobarbituric acid. The results were expressed as $\mu \mathrm{M}$ malondialdehyde (MDA)/100 mL.

The microbiological analyses of E. coli, staphylococci, lactobacilli and Salmonella spp. were determined as Criste et al. (2017) described. The Scan 300 colony counter (Interscience, Paris, France) was used to determine the colony count of E. coli, staphylococci and lactobacilli. The results were expressed as log base 10 colony-forming units (CFU) per gram of caecal contents.

A complete randomized model was used to analyse the data for growth performance, serum biochemical parameters, liver oxidative status and caecal microflora. The effects of treatments were tested by analysis of variance using the GLM procedure of Minitab ${ }^{\circledR}$ Statistical Software, version 17 (State College, Pennsylvania, USA), with treatment as fixed effect. When the overall F-test was significant, differences between means were declared significant at $P<0.05$ using the Tukey test. The comparative graph was done using free software R version 3.5.1 (R Core Team, 2013).

\section{Results and Discussion}

The proximate analysis, total polyphenol content and antioxidant capacity of HWE powder are presented in Table 2. The dietary HWE powder contained a concentration of polyphenols of $4.67 \mathrm{mg}$ gallic acid equivalent per g. Sulaiman et al. (2013) reported that Salix alba bark extract in boiled ethanol has more polyphenols (162 mg gallic acid equivalent per $\mathrm{g}$ ). The differences between the present results and those reported by Sulaiman et al. (2013) may be because differences in solvents that were used in extraction (grain/water as opposed to boiled ethanol), the extraction method (hydro-alcoholic extraction as opposed to Soxhlet), extraction time, and environmental factors. Many researchers have reported major differences in the concentration of polyphenols of willow bark extracts (Durak \& Gawlik-Dziki, 2014; Zabihi et al., 2018; Gligoric et al., 2019). Among the causes of their differences are the part of product that was used and the Salix species. The powder from hydroalcoholic willow bark extract had a total antioxidant capacity of 35.13 $\mathrm{mM}$ equivalent ascorbic acid, $35.97 \mathrm{mM}$ equivalent vitamin E, respectively. Enayat \& Banerjee (2009) showed the importance of the type of solvent used for the extraction of $S$. aegyptiaca bark in the antioxidant assay capacity. However, S. aegyptiaca bark had the highest antioxidant capacity when extracted in ethanol (169 $\pm 28 \mathrm{mg}$ quercetin equivalence /g dried sample), followed by water (78 $\pm 4 \mathrm{mg}$ quercetin equivalence $/ \mathrm{g}$ dried sample) and cyclohexane (10 $\pm 0.1 \mathrm{mg}$ quercetin equivalence $/ \mathrm{g}$ dried sample). Saracila et al. (2018) compared several types of plant extracts (rosehip, buckthorn, grape seeds, sesame and willow buds) in terms of their antioxidant capacity, expressed in inhibition percentages. They showed that the hydroglyceroalcoholic extract of white willow bark has a free radical inhibitory capacity similar to that of grape seed and sesame seed extracts and greater than willow bud extract. 
Table 2 Composition of hydroalcoholic willow bark extract (Salix alba L.)

\begin{tabular}{lc}
\hline Measurements & Composition $(\mathrm{n}=2$ samples $)$ \\
\hline & \\
Dry matter, \% & 99.26 \\
Crude protein, \% & 0.18 \\
Crude fat, \% & 0.01 \\
Crude fibre \% & 1.89 \\
Ash, \% & 0.46 \\
Total polyphenols, mg gallic acid equivalent /g & 4.67 \\
Total antioxidant capacity, mM equivalent ascorbic acid & 35.13 \\
Total antioxidant capacity, mM equivalent vitamin E & 35.97 \\
\hline
\end{tabular}

The bodyweight of T25 and T50 broilers was not significantly different $(P>0.05)$ from that of T0 group (Figure 1). However, the bodyweights attained by the broilers in all three treatments at 14, 21, 28, 35, and 42 days were less than those put forth in the management guide (Anonymous, 2015). This difference was anticipated due to the imposition of heat stress. As Figure 1 shows, this difference increased over time with continued the exposure to heat stress. The results are in agreement with those reported by Saracila et al. (2018), who used $1 \%$ HWE in a diet for broilers (14-42 days old) reared under heat stress $\left(32{ }^{\circ} \mathrm{C}\right)$.

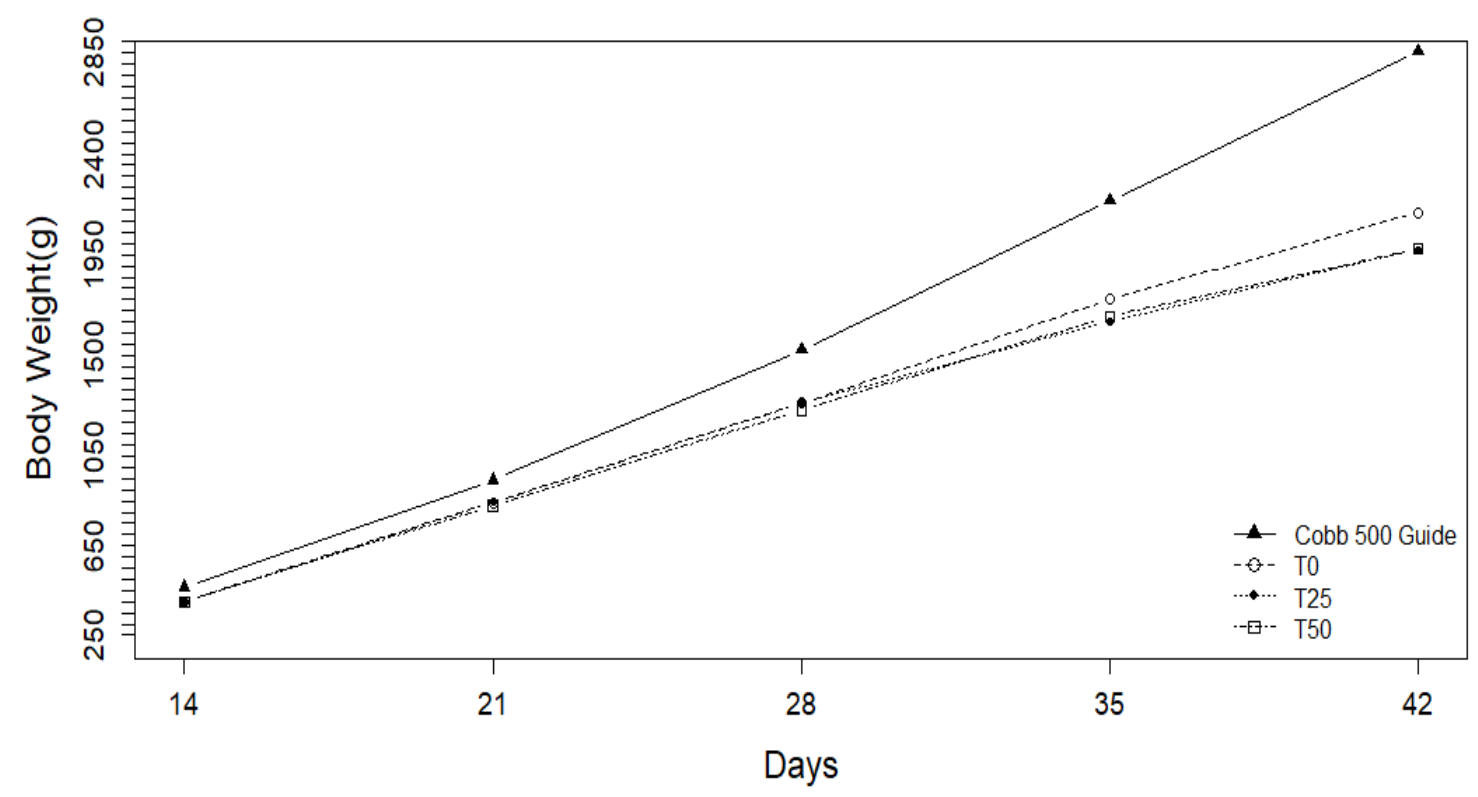

Figure 1 Changes in bodyweight over time of broilers exposed to high heat stress compared with the growth projected for Cobb 500 broilers reared under a recommended temperature regime (Anonymous, 2015) 
Table 3 Effects of diets supplemented with hydroalcoholic willow bark extract powder on the performance of broilers between 14 and 42 days of age

\begin{tabular}{lccccc}
\hline Parameter & T0 & T25 & T50 & SE & $P$-value \\
\hline BWG (g/broiler/day) & & & & & \\
14-35 days & 57.99 & 42.85 & 53.08 & 3.780 & 0.5344 \\
35-42 days & 64.07 & 60.59 & 61.37 & 2.045 & 0.5377 \\
14-42 days & 62.05 & 56.16 & 56.72 & 2.053 & 0.3765 \\
AFI (g feed /broiler/day) & & & & & \\
14-35 days & 109.19 & 101.82 & 93.96 & 5.578 & 0.802 \\
35-42 days & 74.32 & 71.25 & 70.10 & 3.474 & 0.8791 \\
14-42 days & 80.59 & 76.71 & 74.49 & 3.098 & 0.7216 \\
FCR (g feed/g gain) & & & & & \\
14-35 days & 2.00 & 2.37 & 2.20 & 0.103 & 0.5970 \\
35-42 days & 1.16 & 1.18 & 1.17 & 0.059 & 0.9389 \\
14-42 days & 1.33 & 1.39 & 1.35 & 0.058 & 0.9079 \\
& & & & &
\end{tabular}

BWG: bodyweight gain; AFI: average feed intake; FCR: feed conversion ratio

TO: dietary control treatment; T25: dietary control treatment supplemented with hydroalcoholic willow bark extract powder at the level of $25 \mathrm{~g} / 100 \mathrm{~kg}$ diet; T50: dietary control treatment supplemented with hydroalcoholic willow bark extract powder at the level of $50 \mathrm{~g} / 100 \mathrm{~kg}$ diet

No significant differences among diets were observed for average daily feed intake (Table 3). AlFataftah \& Abu-Dieyeh (2007) showed that broilers that were exposed to $30 \pm 2{ }^{\circ} \mathrm{C}$ and $35 \pm 2{ }^{\circ} \mathrm{C}$ had a reduced feed intake (by $12.4 \%$ and $28 \%$ ) and a decreased weight gain (by $18 \%$ and $44 \%$ ) when compared with broilers exposed to constant or variable thermoneutral temperature regimes $\left(24-28^{\circ} \mathrm{C}\right.$ and $25 \pm 2{ }^{\circ} \mathrm{C}$.

There was no effect $(P>0.05)$ of HWE powder on FCR (14-42 days). The addition of HWE powder to the diet $(25 \mathrm{~g} / 100 \mathrm{~kg}$ and $50 \mathrm{~g} / 100 \mathrm{~kg})$ resulted in higher average daily weight gain and improved FCR (Table 3) compared with the results reported by Saracila et al. (2018) when they used 1\% hydroglyceroalcoholic willow bark extract in broiler diets (14-28 days). Although under thermoneutral conditions dietary herbs (Bampidis et al., 2005; Cross et al., 2007) and plant extract supplements (Demir et al., 2005) may be expected to stimulate the growth performance of broilers, there are studies on broilers under heat stress that provide contradictory results (Lee et al., 2003; Hernández et al., 2004).

Many studies have documented lower growth performances for broilers exposed to heat stress (Attia et al., 2011; Ghazi et al., 2012; Zhang et al., 2012; Imik et al., 2013; Olfati et al., 2018). Sohail et al. (2012) showed decreased bodyweight, average daily weight gain, and average feed intake in broilers reared under heat stress compared with those reared under normal temperatures. The data of the current study are in agreement with a recent study by Pirgozliev et al. (2019), which showed that Ross 308 chickens (20-35 days old) that were reared at $35^{\circ} \mathrm{C}$ had reduced feed intake and growth rate and higher FCR compared with those reared at $21^{\circ} \mathrm{C}$. Animals reduce their feed intake under acute and chronic heat stress because of the stimulation of the hypothalamic axis by increasing leptin and adiponectin levels (Lu et al., 2007). Pena et al. (2008) showed that under cyclic heat stress $\left(32^{\circ} \mathrm{C}\right.$ for 5 hours and 19 hours at thermoneutral temperature), the addition of some antioxidants (citric flavonoids and ascorbic acid) to the diet did not affect live performance over the first 32 days of life. Marchini et al. (2011), who studied the effect of cyclic heat stress on performance and carcass yield of broiler chickens, found similar results.

There were no mortalities in the present study. This finding may result from the broilers being kept in a sanitary environment, and thereby possibly leading to diminished efficacy of the dietary additives (Ocak et al. 2008).

The serum profiles (Table 4) revealed several benefits of feeding the broilers reared under heat stress with HWE powder. These serum profiles reflect the health, nutrition, climate and management conditions to which the animals are subjected (Minafra et al., 2010). Levels lipid, protein and enzymatic activity in the blood could indicate the productive performance of the birds and metabolic diseases (Rotava et al., 2008). The blood components in birds are particularly sensitive to changes in ambient temperature, being important indicators of physiological responses to stressing agents (Tawfeek et al., 2014). 
Table 4 Effects of diets supplemented with hydroalcoholic willow bark extract powder on the serum profile of broilers at 42 days of age

\begin{tabular}{lccccrr}
\hline & \multicolumn{2}{c}{ Serum lipid profile } & \multicolumn{2}{c}{ Serum protein profile } & \multicolumn{2}{c}{ Serum enzyme } \\
\cline { 2 - 7 } Treatment & Cholesterol, $\mathrm{mg} / \mathrm{dL}$ & Triglyceride, $\mathrm{mg} / \mathrm{dL}$ & Albumin, $\mathrm{g} / \mathrm{L}$ & Total protein, g/dL & ALT, U/L & AST, U/L \\
\hline \multirow{2}{*}{ T0 } & $123.6^{\mathrm{a}}$ & $50.51^{\mathrm{a}}$ & 1.00 & 2.286 & $5.99^{\mathrm{a}}$ & 261.47 \\
T25 & $124.1^{\mathrm{ab}}$ & $43.94^{\mathrm{ab}}$ & 1.00 & 2.708 & $5.53^{\mathrm{a}}$ & 243.63 \\
T50 & $91.1^{\mathrm{b}}$ & $35.03^{\mathrm{b}}$ & 1.17 & 2.090 & $3.98^{\mathrm{b}}$ & 229.45 \\
SE & 6.5 & 2.50 & 0.06 & 0.106 & 0.314 & 18.63 \\
p-value & 0.0461 & 0.0218 & 0.3911 & 0.0381 & 0.0078 & 0.8075
\end{tabular}

\footnotetext{
${ }^{a, b}$ Means in the same column with different superscripts differ significantly $(P<0.05), \mathrm{n}=8 /$ treatment

TO: dietary control treatment; T25: the dietary control treatment supplemented with hydroalcoholic willow bark extract powder at the level of $25 \mathrm{~g} / 100 \mathrm{~kg}$ diet; T50: the dietary control treatment supplemented with hydroalcoholic willow bark extract powder at the level of $50 \mathrm{~g} / 100 \mathrm{~kg}$ diet; ALT: alanine aminotransferase, AST: aspartate aminotransferase
}

Under heat stress conditions, the cholesterol and triglycerides in the serum of broilers that were fed T50 were significantly less compared with T0. This result could be a consequence of HWE powder leading to a lower catabolic effect in broilers exposed to heat stress. However, serum cholesterol and triglyceride were not affected $(P>0.05)$ by the level of addition of HWE powder to broiler diets. Serum albumin and total protein (Table 4) also did not differ significantly as a function of the treatments. These results partially contradict those reported by Saracila et al. (2018). In the cited study, a significantly lower level of albumin was recorded in the treatment containing willow bark extract (1\%) than in the dietary control treatment, but the level of total protein in the serum of Cobb 500 broilers showed no significant differences between treatments. The alanine aminotransferase (ALT) level $(-50.5 \%)$ in broiler serum from T50 treatment was significantly decreased (-50.5\%) compared with T25 and T0. The literature shows contradictory effects of heat stress on the general health state of broilers. For instance, Jaiswall et al. (2017) showed significant increases in cholesterol (187.42 mg/dL vs. $128.43 \mathrm{mg} / \mathrm{dL}$ ) and triglycerides (165.31 mg/dL vs. $116.15 \mathrm{mg} / \mathrm{dL})$ in the serum of heat challenged broilers, compared with broilers reared under thermoneutral temperatures. On the other hand, the present results are in agreement with those reported by El-Soud et al. (2006), who noted significant decreases in the levels of serum cholesterol of Japanese quail under heat stress that were fed diets containing $0.025 \%, 0.05 \%$, and $0.1 \%$ acetylsalicylic acid. Dudzińska et al. (2015) studied the hypercholesteraemic effect of willow bark and related it to its content of polyphenols. Tawfeek et al. (2014) explained that during heat stress there was greater catabolic effect and concentration of adrenocorticotropic hormone yielding more triglycerides in broiler serum. In a study conducted on the same hybrid (Cobb 500), Attia et al. (2017) showed that the serum cholesterol and serum protein (total protein, albumin) increased significantly in the broilers reared under chronic heat stress $\left(36 \pm 2{ }^{\circ} \mathrm{C}\right)$ compared with broilers reared under normal temperature. They showed that among the transaminases, only aspartate aminotransferase (AST) increased significantly in the serum of broilers exposed to heat stress compared with the broilers reared under normal temperature, ALT not being affected. Furthermore, Imik et al. (2013) showed that the heat stress did not significantly affect the cholesterol, triglycerides, serum protein (total protein, albumin), AST or ALT. The differences in the numerical values that characterize the serum profile in these studies could be due to the analytical methods and equipment, breed, management and diet formulation.

Heat stress increases fat deposits in broilers and induces oxidative damage in tissues. One of the tissues that is most affected is the liver. Levels of malonaldehyde (MDA) in blood and tissues have been used as biomarkers of lipid peroxidation (Yousef et al., 2009; Ismail et al., 2013). The MDA level is directly proportional to the degree of lipid peroxidation (Ismail et al., 2013). Table 5 shows the effect of the supplement of HWE powder on liver MDA concentration in broiler chickens reared under heat stress conditions. In the livers of broilers treated with HWE powder there was a lower $(P<0.05)$ amount of MDA compared with those that were fed the conventional diet (Table 5). This could be because of the antioxidant action of HWE powder to alleviate the oxidative stress caused by the heat. According to Altan et al. (2000), changes in MDA concentration might be regarded as a heat stress response of broilers. Therefore, the level of MDA, as a major product of lipid peroxidation, is an important variable in evaluating oxidative stress (Sim et al., 2003). Erol et al. (2017) showed that a hot environment $\left(34^{\circ} \mathrm{C}\right)$ led to increased MDA concentration in the liver tissues of Ross 308 broilers (24-39 days old) fed a low protein diet. The inclusion of various sources of antioxidants in broiler diets has led to significant reductions of MDA in the liver (Erdoğan et al., 2005;

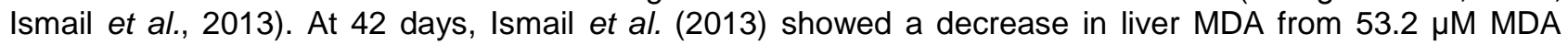


(untreated heat-stressed group) to $18 \mu \mathrm{M}$ MDA, following the addition of zinc bacitracin and ascorbic acid to the diet of broilers exposed to $39{ }^{\circ} \mathrm{C}$. Other studies that investigated the effect of willow bark extract on animal performance showed that it reduced oxidative stress and increased glutathione (which was not determined in this experiment) in various species of animals with arthritis (Khayyal et al., 2005; Sharma et al., 2011). These studies suggest that willow bark extract might suppress oxidative stress by inducing antioxidant enzymes in addition to annihilating free radicals. Ishikado et al. (2013) showed that willow bark extract stimulates the expression of antioxidant enzymes and prevents oxidative stress by activating Nrf2 in the vascular endothelial cells. Thus, the results in tables 4 and 5 indicate an improvement in liver function because of the supplementation.

Table 5 Effects of levels of supplementation with hydroalcoholic willow bark extract powder on liver malonaldehyde concentration ( $\mu \mathrm{M} \mathrm{MDA}$ ) in liver of 42-day old broilers

\begin{tabular}{lc}
\hline Treatment & MDA $(\mu \mathrm{M})$ \\
\hline T0 & $5.850^{\mathrm{a}}$ \\
T25 & $3.820^{\mathrm{b}}$ \\
T50 & $4.14^{\mathrm{b}}$ \\
SE & 0.242 \\
P-value & $<0.0001$
\end{tabular}

\footnotetext{
${ }^{\mathrm{a}, \mathrm{b}}$ Means in the same column with different superscripts differ significantly $(P<0.05), \mathrm{n}=8 /$ treatment

T0: dietary control treatment; T25: the dietary control treatment supplemented with hydroalcoholic willow bark extract powder at the level of $25 \mathrm{~g} / 100 \mathrm{~kg}$ diet; T50: the dietary control treatment supplemented with hydroalcoholic willow bark extract powder at the level of $50 \mathrm{~g} / 100 \mathrm{~kg}$ diet
}

At 35 and 42 days of age, the supplements of HWE powder influenced the $E$. coli count in the caecal content of the broilers significantly (Table 6). Thus, $E$. coli colony forming units were lower $(P<0.05)$ in the caecal content of broilers in T25 and T50 than in T0. The explanation for this effect might be that Salix alba extract had the largest inhibition zones on agar plate against Bacillus cereus $(2.72 \mathrm{~mm})$, Staphylococcus aureus $(1.10 \mathrm{~mm})$, Listeria monocytogenes $(3.08 \mathrm{~mm})$, and E. coli $(0.85 \mathrm{~mm})$ (Pop et al., 2013). At 35 and at 42 days, broilers in T25 and T50 also had lower $(P<0.05)$ staphylococci colony forming units than broilers in T0. Akbarian et al. (2013) highlighted that the antimicrobial efficacy of phytoadditives arose directly from an antimicrobial action or was indirectly mediated by phytogenics to affect the microbiota. Burkholder et al. (2008) noted that heat stress $\left(30^{\circ} \mathrm{C}\right)$ significantly decreased the intestinal bacterial populations of Ross 308 broilers (44 days). Saracila et al. (2018) supported the idea that under heat stress, the dietary hydroglyceroalcoholic willow bark extract (1\%) significantly decreased E. coli and Staphylococci populations in broiler caecums at 42 days. However, at 28 days of age, the $1 \%$ hydroglyceroalcoholic willow bark extract did not influence $(P>0.05)$ the caecum staphylococci populations. A reason for the reduced pathogen populations in the caecum of T25 and T50 broilers may be an antimicrobial effect of the HWE powder. Other studies found antimicrobial effects of willow bark (Pop et al., 2013; Sulaiman et al., 2013), although the antimicrobial effects of HWE powder were not determined in the present study. Sulaiman et al. (2013) observed the greater efficacy of willow bark extract against gram-positive bacteria than against gramnegative bacteria, possibly owing to the differences in their cell wall structure. The gram-negative organisms seem to be more resistant because of their outer membrane, which acts as a barrier to many environmental substances including antibiotics (Kaye et al., 2004). Pop et al. (2013) analysed hot willow bark extract in acidulated water containing $1 \% \mathrm{HCl}$. They found that the extract proved to be rich in eriodyctiol, naringenin and quercetin glucosides, and in catechins, salicylate and isorhamnetin, with all these bioactive molecules being responsible for its antibacterial activity. Additionally, Sulaiman et al. (2013) showed that the antimicrobial and cytotoxic activities of the willow bark extract were positively associated with its antioxidant potentials. Others explain the significant antibacterial property of crude ethanol extract of $S$. alba by the constituents, such as tannins and glycosides, which enable the extract to overcome the barrier of the bacterial cell wall (Scalbert, 1991; Senthamilselvi et al., 2012). Although a great number of articles deal with the antioxidant inhibitory effect on various species of bacteria, only few refer to the effect of antioxidants on probiotic bacteria such as lactobacilli (Välimaa et al., 2007).

The data in Table 6 show that at 35 and at 42 days, more $(P<0.05)$ lactobacilli populations were present in the caecal content of broilers in T25 and T50 than those in T0. At the same time, the greatest 
number of lactobacilli colony forming units $(P<0.05)$ was noted in the caecal content of T50 broilers. The positive effect of plant extracts on gut microbiota include increasing the number of lactic acid bacteria and decreasing the coliform counts in the ileum and caecal contents of broiler chickens (Vidanarachchi et al., 2005). Criste et al. (2019) found that dietary $0.01 \%$ oregano essential oil led to lactobacilli multiplication in the intestinal and caecal segment of Cobb 500 broilers (14-35 days) reared under high temperature.

Table 6 Effects of levels of supplementation with hydroalcoholic willow bark extract powder on caecal bacterial populations (Ig10 colony forming units/g wet caecal content)

\begin{tabular}{|c|c|c|c|c|}
\hline Treatment & E. coli & Staphylococci & Lactobacilli & Salmonella spp. \\
\hline \multicolumn{5}{|c|}{ Determination at 35 days } \\
\hline T0 & $9.936^{\mathrm{a}}$ & $8.161^{\mathrm{a}}$ & $9.557^{\mathrm{a}}$ & absent \\
\hline T25 & $9.922^{b}$ & $7.914^{\mathrm{b}}$ & $9.618^{b}$ & absent \\
\hline T50 & $9.923^{b}$ & $7.900^{b}$ & $9.672^{\mathrm{c}}$ & absent \\
\hline SE & 0.002 & 0.029 & 0.013 & NA \\
\hline$P$-value & 0.0153 & $<0.0001$ & $<0.0001$ & NA \\
\hline \multicolumn{5}{|c|}{ Determination at 42 days } \\
\hline T0 & $10.366^{\mathrm{a}}$ & $8.652^{\mathrm{a}}$ & $10.662^{\mathrm{a}}$ & absent \\
\hline T25 & $10.341^{b}$ & $8.415^{b}$ & $10.715^{\mathrm{b}}$ & absent \\
\hline T50 & $10.340^{b}$ & $8.353^{b}$ & $10.785^{c}$ & absent \\
\hline SE & 0.004 & 0.033 & 0.014 & NA \\
\hline$P$-value & 0.0001 & $<0.0001$ & $<0.0001$ & NA \\
\hline
\end{tabular}

There are several limitations to the generalization of these results as they are specific to the breed, management, diet formulation, analytical methods and equipment that were used in this study. The differences between the concentration of polyphenols in HWE from the present study and that reported by Sulaiman et al. (2013) may in part be due to the solvent used for extraction, the extraction method, the extraction length, and laboratory conditions. Since the most definitive results were obtained at the highest level of HWE supplementation of the broiler diet, further investigations using higher levels of HWE powder (75 $\mathrm{g}$ and $100 \mathrm{~g} / 100 \mathrm{~kg}$ diet) will be conducted under the same environmental conditions.

\section{Conclusions}

Supplementing the diet of broilers with HWE powder did not affect broiler performance (14-42 days old). The treatment supplemented with HWE powder at $50 \mathrm{~g} / 100 \mathrm{~kg}$ of diet significantly decreased cholesterol and triglyceride levels in serum and improved the liver oxidative status. Also, adding HWE powder to the diet had a positive effect in reducing the number of pathogenic bacteria and in increasing the number of lactobacilli in the broiler caecum at 35 and 42 days of age. Because of its antioxidant and antipyretic properties, supplementing each $100 \mathrm{~kg}$ of the diet with $50 \mathrm{~g}$ HWE powder could be a promising solution to the harmful effects of heat-stress on broiler performance, liver oxidative status and caecal microflora.

\section{Acknowledgements} 0102).

This work was supported by a grant of the Romanian Ministry of Education and Research (Project PN 1909

\section{Authors' Contributions}

All the authors contributed equally and commented on the early and final version of manuscript.

\section{Conflict of Interest Declaration}

The authors have no conflict of interest to declare. 


\section{References}

Abidin, Z. \& Khatoon, A., 2013. Heat stress in poultry and the beneficial effects of ascorbic acid (vitamin C) supplementation during periods of heat stress. World's Poultry Science J. 69(01), 135-152. https://doi.org/10.1017/S0043933913000123

Akbarian, A., Golian, A., Kermanshahi, H., Farhoosh, R., Raji, A.R., De Smet S. \& Michiels J., 2013. Growth performance and gut health parameters of finishing broilers supplemented with plant extracts and exposed to daily increased temperature. Spanish J. Agric. Res. 11(1), 109-119. https://doi.org/10.5424/sjar/2013111-3392

Al-Fataftah, A.-R. \& Abu-Dieyeh, Z.H.M., 2007. Effect of chronic heat stress on broiler performance in Jordan. Int. J. Poult. Sci. 6(1), 64-70, ISSN 1682-8356.

Al-Fataftah, A.-R. \& Abdelqader, A., 2013. Effect of Salix and Populus and eucalyptus extracts in drinking water on performance and heat tolerance of broiler chickens during heat stress. American-Eurasian J. Agric. \& Environ. Sci. 13(10), 1309-1313. https://doi.org/10.5829/idosi.aejaes.2013.13.10.76143

Altan, O., Altan, A., Oguz, I., Pabuçcuoglu, A. \& Konyalioglu, S., 2000. Effects of heat stress on growth, some blood variables and lipid oxidation in broilers exposed to high temperature at an early age. Br. Poult. Sci. 41(4), 489493. https://doi.org/10.1080/00071660310001618334

Altınterim, B., 2013. Effects of willow bark (Salix alba) and its salicylates on blood coagulant. Karaelmas Sci. Eng. J. 3(1), 37-39. https://doi.org/10.7212/zkufbd.v3i1.101

Anonymous, 2015. https://www.cobb-vantress.com/resource/management-guides. Cobb-Vantress Inc., Siloam Springs, Arkansas, USA.

Arab Ameri, S., Samadi, F., Dastar, B. \& Zarehdaran, S., 2016. Efficiency of peppermint (Mentha piperita) powder on performance, body temperature and carcass characteristics of broiler chickens in heat stress condition. Iranian Journal of Applied Animal Science. 6(4), 943-950.

Attia, Y.A., Hassan, R.A., Tag El-Din, A.E. \& Abou-Shehema, B.M., 2011. Effect of ascorbic acid or increasing metabolizable energy level with or without supplementation of some essential amino acids on productive and physiological traits of slow-growing chicks exposed to chronic heat stress. J. Anim. Physiol. Anim. Nutr. 95(6), 744-755. https://doi.org/10.1111/j.1439-0396.2010.01104.x

Attia Y.A., Al-Harthi, M.A., El-Shafey, A.S., Rehab, Y.A. \& Kim, W.K., 2017. Enhancing tolerance of broiler chickens to heat stress by supplementation with vitamin E, vitamin C and/or probiotics. Ann. Anim. Sci. 17(4), 1155-1169. https://doi.org/10.1515/aoas-2017-0012

Bampidis, V.A., Christodoulou, V., Florou-Paneri, P., Christaki, E., Chatzopoulou, P.S., Tsiligianni, T. \& Spais, A.B., 2005. Effect of dietary dried oregano leaves on growth performance, carcase characteristics and serum cholesterol of female early maturing turkeys. Br. Poult. Sci. 46(5), 595-601. https://doi.org/10.1080/00071660500256057

Basmacıoğlu, H., Tokuşoğlu, Ö. \& Ergül, M., 2004. The effect of oregano and rosemary essential oils or alpha-tocopheryl acetate on performance and lipid oxidation of meat enriched with n-3 PUFAs in broilers. S. Afr. J. Anim. Sci. 34(3), 197-210.

Burkholder, K.M., Thompson, K.L., Einstein, M.E., Applegate, T.J. \& Patterson, J.A., 2008. Influence of stressors on normal intestinal microbiota, intestinal morphology, and susceptibility to Salmonella enteritidis colonization in broilers. Poult. Sci. 87(9), 1734-1741. https://doi.org/10.3382/ps.2008-00107

Castanon, J.I.R., 2007. History of the use of antibiotic as growth promoters in European poultry feeds. Poult. Sci. 86(11), 2466-2471. https://doi.org/10.3382/ps.2007-00249

Chang Song, R., Ren Xian, J., Ho Myong, K., Wang, J., Zhang, H.J., Wu, S.G. \& Qi, G.H., 2017. Effects of dietary oregano powder supplementation on the growth performance, antioxidant status and meat quality of broiler chicks. Ital. J. Anim. Sci. 16(2), 246-252. https://doi.org/10.1080/1828051X.2016.1274243

Commission of the European Communities, 2009. Regulation (EC) no. 152/ 2009. Methods of sampling and analysis for the official inspection of feeds. Brussels, Belgium.

Criste, R.D., Panaite, T.D., Tabuc, C., Saracila, M., Soica, C. \& Olteanu, M., 2017. Effect of oregano and rosehip supplements on broiler (14-35 Days) performance, carcass and internal organs development and gut health. Agrolife Sci. J. 6(1), 75-83. ISSN Online 2393-2260

Criste, R.D., Panaite, T.D., Saracila, M., Tabuc, C., Bercaru, A. \& Soica, C., 2019. Effect of oregano essential oil as feed additive in broiler diet (14-35 days), reared under heat stress on performance and balance microflora. Proc. 6th International Conference on Poultry Intestinal Health (pp. 231-232), Rome

Cross, D.E., McDevitt, R.M., Hillman, K. \& Acamovic, T., 2007. The effect of herbs and their associated essential oils on performance, dietary digestibility and gut microflora in chickens from 7 to 28 days of age. Br. Poult. Sci. 48(4), 496-506. https://doi.org/10.1080/00071660701463221

Daghir, N.J., 2009. Nutritional strategies to reduce heat stress in broilers and broiler breeders. Lohmann Information 44(1), 6-15. ISSN : 1617-2906.

de Zwart, L.L., Meerman, J.H.N., Commandeur, J.N.M. \& Vermeulen, N.P.E., 1999. Biomarkers of free radical damage markers for atherosclerosis. Free Radical Biology and Medicine, 26(1-2), 202-226. https://doi.org/10.1016/S08915849(98)00196-8

Demir, E., Sarica, Ş., Özcan, M.A. \& Suiçmez, M., 2005. The use of natural feed additives as an alternative to antibiotic growth promoter in broiler diets. Arch. fur Geflugelkd. 69(3), 110-116. ISSN 0003-9098.

Dudzińska, D., Boncler, M. \& Watala, C., 2015. The cardioprotective power of leaves. Arch. Med. Sci. 4: 819-839. https://doi.org/10.5114/aoms.2015.53303

Durak, A. \& Gawlik-Dziki, U., 2014. The study of interactions between active compounds of coffee and willow (Salix sp.) bark water extract. BioMed. Res. Int. 1-11. https://doi.org/10.1155/2014/386953 
El-Soud, S.B.A., Ebeid, T.A. \& Eid, Y.Z., 2006. Physiological and antioxidative effects of dietary acetyl salicylic acid in laying Japanese quail (Coturnix japonica) under high ambient temperature. The Journal of Poultry Science, 43(3), 255-265. https://doi.org/10.2141/jpsa.43.255

Enayat, S. \& Banerjee, S., 2009. Comparative antioxidant activity of extracts from leaves, bark and catkins of Salix aegyptiaca sp. Food Chem. 116(1), 23-28. https://doi.org/10.1016/j.foodchem.2009.01.092

Erdoğan, Z., Erdoğan, S., Aksu, T. \& Baytok, E., 2005. The effects of dietary lead exposure and ascorbic acid on performance, lipid peroxidation status and biochemical parameters of broilers. Turk. J. Vet. Anim. Sci. 29(4), 1053-1059.

Erol, H., Imik, H., Gumus, R. \& Halici, M., 2017. The effects of different amount of protein and vitamin e supplementation in rations on lipid and antioxidant metabolism of broilers exposed to heat stress. Brazilian J. Poult. Sci. 19(2), 289296. https://doi.org/10.1590/1806-9061-2016-0404.

Gavris, T., Untea, A. \& Saracila, M., 2019. Use of phyto-additives in poultry nutrition. Scientific Papers: Animal Science and Biotechnologies. 52 (1),13-18.

Ghazi, S., Habibian, M., Moeini, M.M. \& Abdolmohammadi, A.R., 2012. Effects of different levels of organic and inorganic chromium on growth performance and immunocompetence of broilers under heat stress. Biol. Trace Elem. Res. 146(3), 309-317. https://doi.org/10.1007/s12011-011-9260-1

Gligoric, E., Igic, R., Suvajdžic, L. \& Gruji'c-Letic, N., 2019. Species of the Genus Salix L.: Biochemical screening and molecular docking approach to potential acetylcholinesterase inhibitors. Appl. Sci. 9(9), 1842. doi:10.3390/app9091842

Gu, X.H., Hao, Y. \& Wang, X.L., 2012. Overexpression of heat shock protein 70 and its relationship to intestine under acute heat stress in broilers: 2. Intestinal oxidative stress. Poult. Sci. 91(4), $790-799$. https://doi.org/10.3382/ps.2011-01628

Habibian, M., Ghazi, S., Moeini, M.M. \& Abdolmohammadi, A., 2014. Effects of dietary selenium and vitamin E on immune response and biological blood parameters of broilers reared under thermoneutral or heat stress conditions. Int. J. Biometeorol. 58(5), 741-752. https://doi.org/10.1007/s00484-013-0654-y.

Hajati, H., Hassanabadi, A., Golian, A, Nassiri-Moghaddam, H. \& Nassiri M.R., 2015. The effect of grape seed extract and vitamin $\mathrm{C}$ feed supplementation on some blood parameters and HSP70 gene expression of broiler chickens suffering from chronic heat stress. Italian Journal of Animal Science 14 (3), 3273.

Hernández, F., Madrid, J., García, V., Orengo, J. \& Megías, M.D., 2004. Influence of two plant extracts on broilers performance, digestibility, and digestive organ size. Poult. Sci. 83(2), 169-174. https://doi.org/10.1080/0007166031000085508

Huang, S.C., Fu, Y.F., Lan, Y.F., Rehman, M.U. \& Tong, Z.X., 2018. Histopathological and biochemical evaluations of the kidney in broiler chickens under acute heat stress conditions. Indian Journal of Animal Research52(4), 637639. https://doi.org/10.18805/ijar.v0iOF.7652

Imik, H., Kaynar, O., Ozkanlar, S., Gumus, R., Polat, H. \& Ozkanlar, Y., 2013. Effects of vitamin C and alpha-lipoid acid dietary supplementations on metabolic adaptation of broilers to heat stress. Rev. Med. Vet. (Toulouse) 164(2), 5259. ISSN : 0035-1555

Ishikado, A., Sono, Y., Matsumoto, M., Robida-Stubbs, S., Okuno, A., Goto, M. \& Makino, T., 2013. Willow bark extract increases antioxidant enzymes and reduces oxidative stress through activation of Nrf2 in vascular endothelial cells and Caenorhabditis elegans. J. Free Radic. Biol. Med. 65, 1506-1515.

Ismail, I.B., Al-Busadah, K.A. \& El-Bahr, S.M., 2013. Oxidative stress biomarkers and biochemical profile in broilers chicken fed zinc bacitracin and ascorbic acid under hot climate. American Journal of Biochemistry and Molecular Biology 3(2), 202-214. https://doi.org/10.3923/ajbmb.2013.202.214

Jaiswal, S.K., Raza, M. \& Chaturvedani, A.K., 2017. Effect of thermal stress on serum biochemical and haematological parameters in broiler chickens. The Indian Journal of Veterinary Sciences and Biotechnology 12(3), 19-22. https://doi.org/10.21887/ijvsbt.v12i3.7082

Jakubcova, Z., Zeman, L., Mares, P., Mlcek, J., Jurikova, T., Dostalova, L. \& Sochor, J., 2014. Effect of chamomile supplements to feeding doses on antimicrobial parameters in poultry. Potravinarstvo, 8(1), 228-232.

Kamboh, A.A., Hang, S.Q., Bakhetgul, M. \& Zhu, W.Y., 2013. Effects of genistein and hesperidin on biomarkers of heat stress in broilers under persistent summer stress. Poult. Sci. 92(9), 2411-2418. https://doi.org/10.3382/ps.201202960

Kaye, K.S., Engemann, J.J., Fraimow, H.S. \& Abrutyn, E., 2004. Pathogens resistant to antimicrobial agents: Epidemiology, molecular mechanisms, and clinical management. Infectious Disease Clinics of North Americ, 18(3), 467-511. https://doi.org/10.1016/j.idc.2004.04.003

Khayyal, M., El-Ghazaly, M., Abdallah, D., Okpanyi, S., Kelber, O. \& Weiser, D., 2005. Mechanisms involved in the antiinflammatory effect of a standardized willow bark extract. Arzneimittelforschung 55(11), 677-687. https://doi.org/10.1055/s-0031-1296917

Lee, K.-W., Everts, H., Kappert, H.J., Frehner, M., Losa, R. \& Beynen A.C., 2003. Effects of dietary essential oil components on growth performance, digestive enzymes and lipid metabolism in female broiler chickens. Br. Poult. Sci. 44(3), 450-457. https://doi.org/10.1080/0007166031000085508

Lu, Q., Wen, J. \& Zhang, H., 2007. Effect of chronic heat exposure on fat deposition and meat quality in two genetic types of chicken. Poult. Sci. 86(6), 1059-1064. https://doi.org/10.1093/ps/86.6.1059

Ma, J.S., Chang, W.H., Liu, G.H., Zhang, S., Zheng, A.J., Li, Y. \& Cai, H.Y., 2015. Effects of flavones of sea buckthorn fruits on growth performance, carcass quality, fat deposition and lipometabolism for broilers. Poult. Sci. 94(11), 2641-2649. https://doi.org/10.3382/ps/pev250 
Mahdi, J.G., 2010. Medicinal potential of willow: A chemical perspective of aspirin discovery. Journal of Saudi Chemical Society 14, 317-322. https://doi.org/10.1016/j.jscs.2010.04.010

Marchini, C.F., Silva, P.L., Nascimento, M.R.B., Beletti, M., Silva, N. \& Guimaraes, E., 2011. Body weight intestinal morphometry and cell proliferation of broiler chickens submitted to cyclic heat stress. Int. J. Poult. Sci. 10(6), 455460. https://doi.org/10.17533/udea.rccp.v29n3a01

Minafra, C.S., Marques, S.F.F., Stringhini, J.H., Ulhoa, C.J., Minafra e Rezende, C.S., Santos, J.S. \& de Moraes, G.H.K., 2010. Biochemical serum profile of broilers fed diets supplemented with alfa-amylase from Cryptococcus flavus and Aspergillus niger HM2003. Rev. Bras. Zootec. 39(12): 2691-2696.

Nahrstedt, A., Schmidt, M., Khayyal, M.T., Jäggi, R. \& Metz, J., 2007. Willow bark extract: The contribution of polyphenols to the overall effect. Wiener Medizinische Wochenschrift, 157(13-14), 348-351. https://doi.org/10.1007/s10354-007-0437-3

Nisar, A.N., Sultana, M. \& Waiz, A.H., 2013. Oxidative stress - Threat to animal health and production. Int. J. Livest. Res. 3(2), 76-83. ISSN 2277-1964 online

Ocak, N., Erener, G., Ak, F.B., Sungu, M., Altop, A. \& Ozmen, A., 2008. Performance of broilers fed diets supplemented with dry peppermint (Mentha piperita L.) or thyme (Thymus vulgaris L.) leaves as growth promoter source. Czech J. Anim. Sci., 53(4), 169-175.

Olfati, A., Mojtahedin, A., Sadeghi, T., Akbari, M. \& Martínez-Pastor, F., 2018. Comparison of growth performance and immune responses of broiler chicks reared under heat stress, cold stress and thermoneutral conditions. Spanish Journal of Agricultural Research, 16(2), e0505. https://doi.org/10.5424/sjar/2018162-12753

Panaite, T., Criste, R.D., Saracila, M., Tabuc, C., Turcu, P. \& Olteanu, M., 2018. The use of ascorbic acid and Artemisia annua powder in diets for broilers reared under heat stress. Romanian Biotechnological Letters 23(5), 1397613985. https://doi.org/10.26327/RBL2018.159

Pena, J., Vieira, S., Lopez, J., Reis, R., Barros, R., Furtado, F. \& Silva, P., 2008. Ascorbic acid and citric flavonoids for broilers. Braz. J. Poult. Sci. 10(2), 125-130. http://dx.doi.org/10.1590/S1516-635X2008000200008

Piestun, Y., Druyan, S., Brake, J. \& Yahav, S., 2013. Thermal manipulations during broiler incubation alter performance of broilers to 70 days of age. Poult. Sci. 92, 1155-1163. https://doi.org/10.3382/ps.2012-02609

Pirgozliev, V., Rose, S.P., Atanasov, A., Stankiewicz, A., Whiting, I.M. \& Mansbridge, S.C., 2019. The impact of high rearing temperature on the performance, villus morphometry and relative expression of some genes in chickens. Proc. 6th International Conference on Poultry Intestinal Health (p. 77).

Pop, C., Vodnar, D., Ranga, F. \& Socaciu, C., 2013. Comparative antibacterial activity of different plant extracts in relation to their bioactive molecules, as determined by LC-MS analysis. Bulletin UASVM Animal Science and Biotechnologies, 70(1), 86-94. http://journals.usamvcluj.ro/index.php/zootehnie/issue/archive

Prieto, P., Pineda, M. \& Aguilar, M., 1999. Spectrophotometric quantitation of antioxidant capacity through the formation of a phosphomolybdenum complex: Specific application to the determination of vitamin E. Analytical Biochemistry 269(2), 337-341. https://doi.org/10.1006/abio.1999.4019

R Core Team, 2013. R: A language and environment for statistical computing. R Foundation for Statistical Computing, Vienna, Austria. http://www.R-project.org/.

Rotava, R., Zanella, I., Karkow, A.K., Dullius, A.P., Picolli, L. \& Denardin, C.C., 2008. Blood biochemistry of poultry fed with grape by-products Agrarian 1, 91-104 (Portuguese).

Saracila, M., Criste, R., Panaite, T., Vlaicu, P., Tabuc, C., Turcu, R. \& Olteanu, M., 2018. Artemisia Annua as phytogenic feed additive in the diet of broilers (14-35 Days) reared under heat stress (32 $\left.{ }^{\circ} \mathrm{C}\right)$. Brazilian J. Poult. Sci. 20(4), 825-832. http://dx.doi.org/10.1590/1806-9061-2018-0772

Saracila, M., Panaite, T.D., Vlaicu, P.A., Tabuc, C., Palade, M.L., Gavris, T. \& Criste, R.D., 2018. Dietary willow bark extract for broilers reared under heat stress. Animal Science and Biotechnologies 75(2). https://doi.org/ 10.15835/buasvmcn-asb:2018.0011 [could not find]

Saracila, M., Tabuc, C., Panaite, T.D., Papuc, C.P., Olteanu, M. \& Criste, R.D., 2018. Effect of the dietary willow bark extract (Salix alba) on the caecal microbial population of broilers $\left(14-28\right.$ days) reared at $32^{\circ} \mathrm{C}$. Agriculture for Life, Life for Agriculture Conference Proceedings 1(1), 155-161. https://doi.org/10.2478/alife-2018-0023

Scalbert, A., 1991. Antimicrobial properties of tannins. Phytochemistry 30(12), 3875-3883. https://doi.org/10.1016/00319422(91)83426-L

Seidavi, A., Tavakoli, M., Diarra, S.S., Abdelfattah, Z. \& SalemArab, M., 2018. Recent advances in the practical usages of some trees/shrubs as ingredient of poultry diets. Agroforest Syst. 1-8. https://doi.org/10.1007/s10457-0180315-6

Senthamilselvi, M.M., Kesavan, D. \& Sulochana, N., 2012. An anti-inflammatory and anti-microbial flavone glycoside from flowers of Cleome viscosa. Organic and Medicinal Chemistry Letters 2(1), 19, https://doi:10.1186/21912858-2-19. https://doi.org/10.1186/2191-2858-2-19

Shara, M. \& Stohs, S.J., 2015. Efficacy and safety of white willow bark (Salix alba) extracts. Phytotherapy Res. 29(8), 1112-1116. https://doi.org/10.1002/ptr.5377

Sharma, S., Sahu, D., Das, H.R. \& Sharma, D., 2011. Amelioration of collagen-induced arthritis by Salix nigra bark extract via suppression of pro-inflammatory cytokines and oxidative stress. Food and Chemical Toxicology, 49(12), 3395-3406. https://doi.org/10.1016/j.fct.2011.08.013

Shi, D., Bai, L., Qu, Q., Zhou, S., Yang, M., Guo, S. \& Liu, C., 2019. Impact of gut microbiota structure in heat-stressed broilers. Poult. Sci. pez026. https://doi.org/10.3382/ps/pez026

Sim, A.S., Salonikas, C., Naidoo, D. \& Wilcken, D.E.L., 2003. Improved method for plasma malondialdehyde measurement by high-performance liquid chromatography using methyl malondialdehyde as an internal standard. J. Chromatogr. B. 785(2), 337-344. https://doi.org/10.1016/S1570-0232(02)00956-X 
Sohail, M.U., Hume, M.E., Byrd, J.A., Nisbet, D.J., ljaz, A., Sohail, A. \& Rehman, H., 2012. Effect of supplementation of prebiotic mannan-oligosaccharides and probiotic mixture on growth performance of broilers subjected to chronic heat stress. Poult. Sci. 91(9), 2235-2240. https://doi.org/10.3382/ps.2012-02182

St-Pierre, N.R., Cobanov, B. \& Schnitkey, G., 2010. Economic losses from heat stress by US livestock industries. Journal of Dairy Science, 86(31), E52-E77. https://doi.org/10.3168/jds.S0022-0302(03)74040-5

Sulaiman, G.M., Hussien, N.N., Marzoog, T.R. \& Awad, H.A., 2013. Phenolic content, antioxidant, antimicrobial and cytotoxic activities of ethanolic extract of Salix alba. Am. J. Biochem. Biotechnol. 9(1), 41-46. Doi: 10.3844/ajbbsp.2013.41.46

Tawfeek, S.S., Hassanin, K.M.A. \& Youssef, I.M.I., 2014. The effect of dietary supplementation of some antioxidants on performance, oxidative stress, and blood parameters in broilers under natural summer conditions. Journal of World's Poultry Research, 4(1), 10-19.

Tugay, A., 2015. Use of Moringa oleifera in poultry and ruminant nutrition. Turkish Journal of Agriculture -Food Science and Technology 3(6), 425-429. https://doi.org/10.24925/turjaf.v3i6.425-429.327

Untea, A., Lupu, A., Saracila, M. \& Panaite, T., 2018. Comparison of ABTS, DPPH, phosphomolybdenum assays for estimating antioxidant activity and phenolic compounds in five different plant extracts. Animal Science and Biotechnologies, 75(2). https://doi.org/10.15835/buasvmcn-asb:2018.0009

Välimaa, A.-L., Honkalampi-Hämäläinen, U., Pietarinen, S., Willför, S., Holmbom, B. \& Von Wright, A., 2007. Antimicrobial and cytotoxic knotwood extracts and related pure compounds and their effects on food-associated microorganisms. Int. J. Food Microbiol. 115(2), 235-243. https://doi.org/10.1016/j.ijfoodmicro.2006.10.031

Vidanarachchi, J.K., Mikkelsen, L.L., Sims, I., Iji, P. A \& Choct, M., 2005. Phytobiotics: alternatives to antibiotic growth promoters in monogastric animal feeds. Recent Advances in Animal Nutrition in Australia 15 (Kamel 2001), 131144.

Vlachojannis, J., Magora, F. \& Chrubasik, S., 2011. Willow species and aspirin: Different mechanism of actions. Phytother. Res. 25, 1102-1104. https://doi.org/10.1002/ptr.3386

Vlaicu, P.A., Saracila, M., Panaite, T.D., Tabuc, C., Bobe, E. \& Criste, R.D., 2017. Effect of the dietary grape seeds and rosehip oils given to broilers (14-42 days) reared at $32^{\circ} \mathrm{C}$ on broiler performance, relative weight of carcass cuts and internal organs and balance of gut microflora. Archiva Zootechnica 20(1), 77-88.

Wang, W.C., Yan, F.F., Hu, J.Y., Cheng, H.W. \& Amen, O.A., 2018. Supplementation of Bacillus subtilis-based probiotic reduces heat stress-related behaviors and inflammatory response in broiler chickens. J. Anim. Sci. 96(5), 16541666. https://doi.org/10.1093/jas/sky092

Yegani, M. \& Korver, D.R., 2008. Factors affecting intestinal health in poultry. Poult. Sci. 87(10), 2052-2063. https://doi.org/10.3382/ps.2008-00091

Yousef, M.I., Saad, A.A. \& El-Shennawy, L.K., 2009. Protective effect of grape seed proanthocyanidin extract against oxidative stress induced by cisplatin in rats. Food Chem. Toxicol. 47(6), 1176-1183. https://doi.org/10.1016/j.fct.2009.02.007

Zabihi, A. N., Mahmoudabady, M., Soukhtanloo, M., Hayatdavoudi, P., Beheshti, F. \& Niazmand, S., 2018. Salix alba attenuated oxidative stress in the heart and kidney of hypercholesterolemic rabbits. Avicenna J. Phytomedicine. 8(1), 63-72.

Zhang, Z.Y., Jia, G.Q., Zuo, J.J., Zhang, Y., Lei, J., Ren, L. \& Feng, D.Y., 2012. Effects of constant and cyclic heat stress on muscle metabolism and meat quality of broiler breast fillet and thigh meat. Poult. Sci. 91(11), 2931-2937. https://doi.org/10.3382/ps.2012-02255 